\title{
Enhanced oxidative damage to DNA, lipids, and proteins and levels of some antioxidant enzymes, cytokines, and heat shock proteins in patients infected with influenza H1N1 virus
}

\author{
J.-Y. LIM ${ }^{1 \#}$, E. OH ${ }^{2 \#}$, Y. KIM ${ }^{1}$, W.-W. JUNG ${ }^{3}$, H.-S. KIM ${ }^{4}$, J. LEE ${ }^{*}$, D. SUL ${ }^{*}$
}

\begin{abstract}
${ }^{1}$ Graduate School of Medicine, Korea University, 126-1 Anam-Dong 5-Ka, Sungbukku, Seoul 136-701, Republic of Korea; ${ }^{2}$ Center for Life and Environmental Science, Seegene Medical Foundation, 2-3, Yongdap-Dong, Sungdongku, Seoul 133-847, Republic of Korea;

${ }^{3}$ Department of Biomedical Laboratory Science, College of Health Science, Cheongju University, 298 Daeseongro, Sangdangku, Cheongju Chungbuk 360-764, Republic of Korea; ${ }^{4}$ Department of Clinical Pathology, College of Health Science, Korea University, San 1, Jeongreung-Dong, Sungbuk-Ku, Seoul, 136-703, Republic of Korea; ${ }^{5}$ Department of Internal Medicine, College of Medicine, Hallym University, 1 Hallymdaehak-gil, Chuncheon, Ganwon-Do 200-702, Republic of Korea
\end{abstract}

Received January 15, 2014; accepted August 5, 2014

\begin{abstract}
Summary. - Influenza virus is well known for pandemics and epidemics with high morbidity. Many studies have been focused to this problematics, however, oxidative damage to DNA, lipids, and proteins and the expression of cytokines, antioxidant enzymes and heat-shock proteins (HSPs) in H1N1 virus-infected patients has not been investigated yet. Therefore we aimed this study at these issues. We found out that patients infected with the 2011 H1N1 virus as compared to control subjects exhibited an increased oxidative damage to DNA, lipids and proteins as assayed by levels of 8-hydroxydeoxyguanosine (8-OhdG) and malondialdehyde (MDA) and carbonyl content in plasma and urine. Moreover, the levels of antioxidant enzymes SOD and catalase, cytokines Il-6, 1L-10 and TNF- $\alpha$ and HSPs 90 and 27 were also significantly higher in the H1N1-infected patients. Our results suggest that the influenza $\mathrm{H} 1 \mathrm{~N} 1$ virus is a strong inducer of (i) oxidative damage to DNA, lipids, and proteins, (ii) antioxidant enzymes, (iii) cytokines and (iv) HSPs.
\end{abstract}

Keywords: influenza H1N1 virus; patients; oxidative damage; antioxidant enzymes; cytokines; heat-shock proteins

\section{Introduction}

Influenza virus is well known for the worldwide pandemic and epidemic, and is a highly invasive virus that causes high level of morbidity. The first confirmed case of novel influenza A (H1N1) infection in Korea was registered on May 1, 2009

*Corresponding authors. E-mail: dsul@korea.ac.kr, litjacob@chol. com; phone: +82-2-920-6614. ${ }^{*}$ These authors contributed equally to this work.

Abbreviations: 8-OhdG $=8$-hydroxydeoxyguanosine; $\mathrm{SOD}=$ superoxide dismutase; $\mathrm{IL}=$ interleukin; TNF- $\alpha=$ tumor necrosis factor alpha; $\mathrm{MDA}=$ malondialdehyde; $\mathrm{Prx}=$ peroxiredoxin HSPs $=$ heat shock proteins; ROS = reactive oxygen species and 225 deaths had been reported by January 1, 2010 (Choi et al., 2012).

Virus-induced activation of phagocytes is associated with oxidative stress, not only because reactive oxygen species (ROS) are released but also because activated phagocytes may release pro-oxidant cytokines and interleukins (Kohen and Nyska, 2002). Among ROS, hydroxy radicals are powerful oxidizing agents that can react at a high rate with most organic and inorganic molecules in the cell, including DNA, proteins, lipids, amino acids, sugars, and metals (Kohen and Nyska, 2002). A number of studies concerned with oxidative damage, including DNA damage and lipid peroxidation caused by the influenza virus infection have been performed (Vijaya et al., 1999; Kumar et al., 2003; Nikam et al., 2010). 
In addition, influenza virus enhances the induction of proinflammatory cytokines, including IL-1, IL-2, IL-6, IL-8, IL-10, and TNF- $\alpha$, which may lead to disease progression (Arankalle et al., 2010; Damjanovic et al., 2011; Gao et al., 2011; Hasegawa et al., 2011; Yu et al., 2011).

However, it has been reported that the antioxidant enzymes, such as superoxide dismutase 1 (SOD-1), and 2 (SOD-2), catalase, heme oxygenase (HO), glutathione peroxidase $(\mathrm{GPx})$, peroxiredoxin (Prx), and indoleamine 2,3-dioxygenase (IDO), are involved in the protective mechanism against influenza virus infection through scavenging of the ROS (Jacoby and Choi, 1994; Choi et al., 1996; Shi et al., 2010; Yamada et al., 2012; Yatmaz et al., 2013).

On the other hand, HSPs including, HSP40, 70, and 90, play a role in the assembly and nuclear import of influenza virus RNA polymerase, in stimulating influenza virus activity that mediates apoptosis, and in regulating the activity of dsRNA dependent protein kinase that inhibits innate immune responses (Watanabe et al., 2006; Sharma et al., 2011; Zhang et al., 2011).

Many studies have been performed to elucidate these finding; however, oxidative damage, and the expression of cytokines, antioxidant enzymes, and HSPs have not been investigated in $\mathrm{H} 1 \mathrm{~N} 1$ infected patients. Therefore, in this study, we investigated the oxidative damage to DNA, lipids, and proteins and the expression of cytokines, antioxidant enzymes and HSPs in influenza $2011 \mathrm{H} 1 \mathrm{~N} 1$ virus-infected patients compared to non-infected subjects.

\section{Materials and Methods}

Patients. H1N1 infected patients and control subjects were enrolled in this study from November 2010 to March 2011. Fifteen $\mathrm{H} 1 \mathrm{~N} 1$ infected patients and non-infected control subjects were involved in this study. Patients consisted of 13 female and 2 male and their age ranged from 21 to 56 years ( $35.6 \pm 10.7$ years). Control subjects comprised of healthy female volunteers, and their age ranged from 21 to 48 years ( $34.7 \pm 8.7$ years). No significant difference in terms of age was observed between the two groups. Nasopharyngeal swab samples collected from all of the subjects were tested for H1N1 infection by real-time PCR. Viral RNA was extracted from nasopharyngeal swab samples, using QIAamp viral RNA mini kit (Qiagen) according to the manufacturers' instructions. Influenza real-time PCR was performed using primers and probes described in the CCDC A (H1N1) influenza guidance. Blood and urine samples were collected from all of the study subjects. This study was approved by the Ethics Committee of Hanrim University Hospital.

8-OhdG assay. The level of urinary 8-OhdG was assayed using a commercially available ELISA kit (New 8-OhdG check; Japan Institute for the Control of Aging, Japan). Urine samples were centrifuged at 2,000 $\mathrm{g}$ for $15 \mathrm{~min}$ and $50 \mathrm{ml}$ of the supernatant were collected and assayed according to the manufacturer's instructions.

MDA assay. The level of MDA was measured as described previously (Kim et al., 2006). MDA in the plasma was measured using HPLC (Gilson) equipped with a Spherisorb ODS $5 \mu \mathrm{m}$ column (Waters Corporation, USA). Fifty $\mu$ l of the plasma were mixed with $50 \mu \mathrm{l}$ of $0.05 \%$ butylated hydroxytoluen, $400 \mu \mathrm{l}$ of $0.44 \mathrm{~mol} / \mathrm{l}$ phosphoric acid solution, and $100 \mu$ of thiobarbituric acid (TBA) solution. The samples were then incubated in $100^{\circ} \mathrm{C}$ water bath for $1 \mathrm{hr}$. After incubation, the TBA-MDA precipitate was extracted with $\mathrm{n}$-butanol. Aliquots of $100 \mu \mathrm{l}$ were then removed from the n-butanol layer and injected into the HPLC system. Standards and quality control samples were prepared using 97\% 1,1,3,3-tetraethoxypropane $(0,0.125,0.5,1.0$, and $2.0 \mu \mathrm{mol} / \mathrm{l})$.

Carbonyl content assay. The levels of protein carbonyls in the plasma were determined using a spectrophotometric DNPH assay as described previously (Kim et al., 2006). Briefly, $100 \mu \mathrm{l}$ of plasma was mixed with $400 \mu \mathrm{l}$ of buffer solution. After mixing, $500 \mu \mathrm{l}$ of $30 \%$ TCA was added to each tube, vortexed and placed on ice for $10 \mathrm{~min}$. The final precipitate was resolved in $1 \mathrm{ml}$ of $6 \mathrm{~mol} / \mathrm{l}$ guanidine $\mathrm{HCl}$. The carbonyl contents were calculated from the absorbance measurement at $380 \mathrm{~nm}$ using the absorption coefficient of $22,000 \mathrm{~mol} / \mathrm{cm}$. The absorbance $\mathrm{A}_{380}$ was also determined for the sample treated with DNPH and $\mathrm{HCl}$, which was subtracted as a background

RT-PCR for antioxidant enzymes. Total RNA was purified from the whole human blood using the RNeasy mini kit (Qiagen), according to the manufacturer's protocol. One microgram of total RNA was reverse transcribed by SuperScript II (Invitrogen), using an oligo-dT primer as described by the manufacturer (Table 1).

Western blot assay of cytokines and HSPs. Protein content in the human plasma was determined using the Bradford protein assay kit (Bio-Rad Laboratory, USA) and bovine serum albumin standards. A $12.5 \sim 100 \mu \mathrm{g}$ sample was separated by $6.5 \sim 12 \%$ SDS-PAGE and blotted onto PVDF membranes (Millipore Corporation, USA) at $400 \mathrm{~mA}$ for $2 \mathrm{hr}$. The PVDF membranes were blocked with 5\% skim milk buffer and then probed with the respective primary antibodies. After washing, the membranes were incubated with the

Table 1. Primers used in RT-PCR

\begin{tabular}{|c|c|c|}
\hline Gene & Forward primer & Reverse primer \\
\hline Catalase & 5'-TTT CCC AGG AAG ATC CTG AC-3' & 5'-ACC TTG GTG AGA TCG AAT GG-3' \\
\hline SOD-1 & 5'-GGT GGG CCA AAG GAT GAA GAG-3' & 5'-CCA CAA GCC AAA CGA CTT CC-3' \\
\hline Prx-1 & 5'-CCA CGG AGA TCA TTG CTT TCA-3' & 5'-AGG TGT ATT GAC CCA TGC TAG AT-3' \\
\hline
\end{tabular}




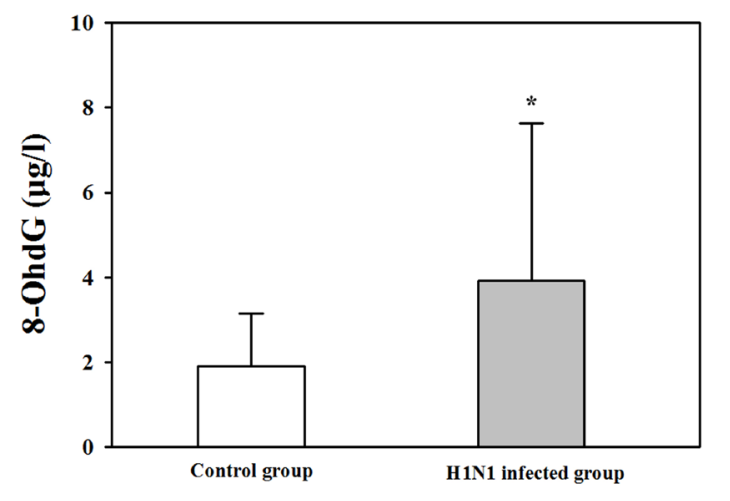

Fig. 1

Urinary 8-OhdG levels

The level of urinary 8-OhdG was assayed using a commercially available ELISA kit in the non-infected control group $(n=15)$ and H1N1 infected group $(n=15)$. Data represent mean \pm S.D. Asterisk indicates a significant difference.

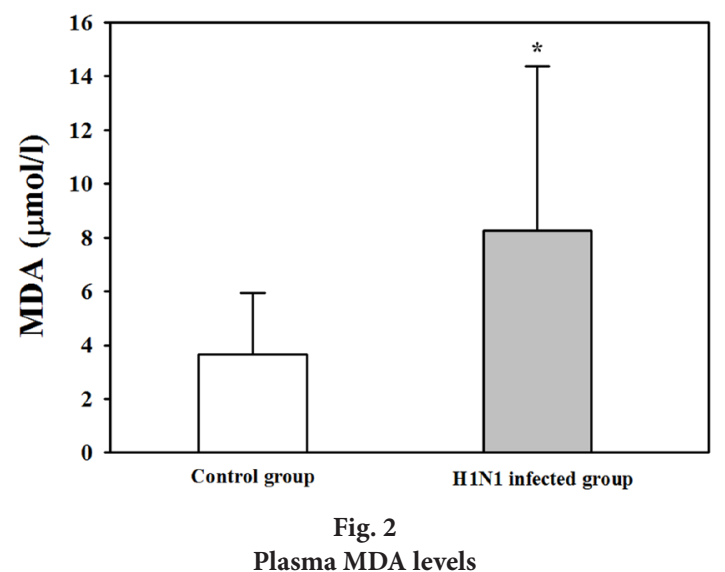

Lipid peroxidation was determined using MDA assay in the plasma of noninfected control group $(n=15)$ and H1N1 infected group $(n=15)$. Data represent mean \pm S.D. Asterisk indicates a significant difference.

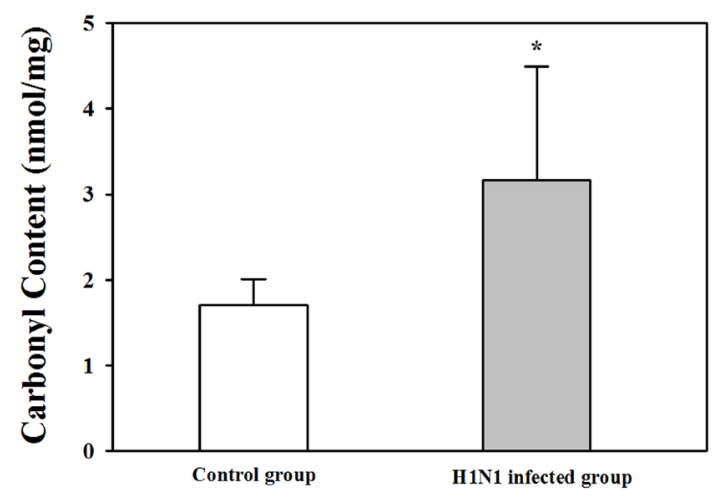

Fig. 3

Plasma carbonyl contents

Protein oxidation was determined using a spectrometric DNPH assay in the plasma of non-infected control group $(n=15)$ and H1N1 infected group $(n=15)$. Data represent mean \pm S.D. Asterisk indicates a significant difference. corresponding secondary antibody. HRP was detected by chemiluminescence (Amersham ECL kit) and the film was scanned by Epson Expression 10,000× L scanner, and band intensities were analyzed with an Image J program.

Statistical analysis. Statistical analyses were performed using SAS version 8.2. We used the analysis of variance (ANOVA) method with Duncan and Tukey's tests to determine the differences between the two groups. The level of statistical significance employed in all cases was $p \leq 0.05$.

\section{Results}

DNA damage was assessed by determining the urinary 8-OhdG concentration by ELISA in the H1N1 infected group and control group. The mean values of $8-\mathrm{OhdG}$ in urine of the control group and $\mathrm{H} 1 \mathrm{~N} 1$ infected group were $1.90 \pm 1.24$ and $3.92 \pm 3.70 \mu \mathrm{g} / \mathrm{l}$, respectively. The production of urinary 8-OhdG in H1N1 infected patients was significantly increased when compared to that in the control subjects (Fig. 1).

Lipid peroxidation was evaluated by the thiobarbituric acid reactive substances method in the plasma of the two groups. As shown in Fig 2, the production of MDA in the H1N1 infected group was significantly increased when compared to that in the control group. The mean MDA values of the control and $\mathrm{H} 1 \mathrm{~N} 1$ infected groups were $3.64 \pm 2.31$ and $8.26 \pm 6.12 \mu \mathrm{mol} / \mathrm{l}$, respectively (Fig 2).

Protein oxidation was examined by determining the levels of carbonyl contents in amino acids by derivatization with 2,4-dinitrophenyl hydrazine. The results of protein oxidation in the plasma of the H1N1 infected and control groups are summarized in Fig. 3. The mean values of carbonyl contents in the control group and $\mathrm{H} 1 \mathrm{~N} 1$ infected group were $1.71 \pm 0.30$ and $3.16 \pm 1.33 \mathrm{nmol} / \mathrm{mg}$ proteins, respectively. The level of protein oxidation was significantly greater in the H1N1 infected group than in the control group (Fig. 3)

The protein and gene expression levels of SOD-1, catalase and Prx-1 were determined in the plasma and leucocytes obtained from the H1N1 infected group and control group (Fig. $4 \mathrm{a}$ and $\mathrm{b}$ ). Similar results were obtained for protein and gene expressions of antioxidant enzymes including, SOD-1, catalase and Prx-1. There was no statistically significant difference in the gene expression of Prx 1 between the H1N1 infected group and control group. However, the expression levels of SOD-1 and catalase genes were significantly greater in the H1N1 infected group than in the control group (Fig. 4b).

Western blot analysis of IL-1 $\beta$, IL-6, and TNF- $\alpha$ expression was conducted using the plasma obtained from the H1N1 infected group and control group (Fig. 5). There was no statistically significant difference in the expression of IL- $1 \beta$ between the H1N1 infected group and control group. However, the expression levels of IL- 6 and TNF- $\alpha$ were significantly greater in the H1N1 infected group than in the control group. 

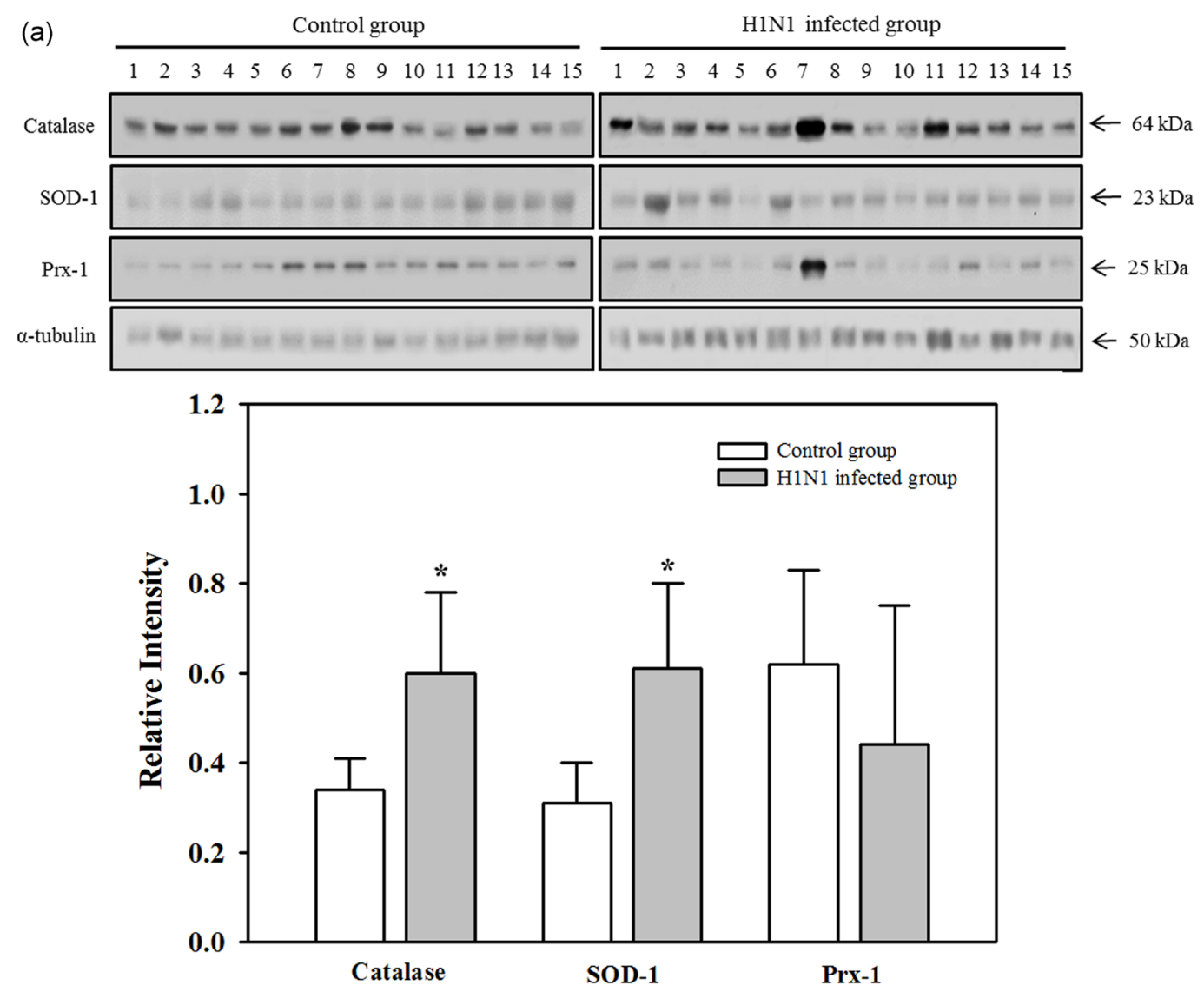

(b)

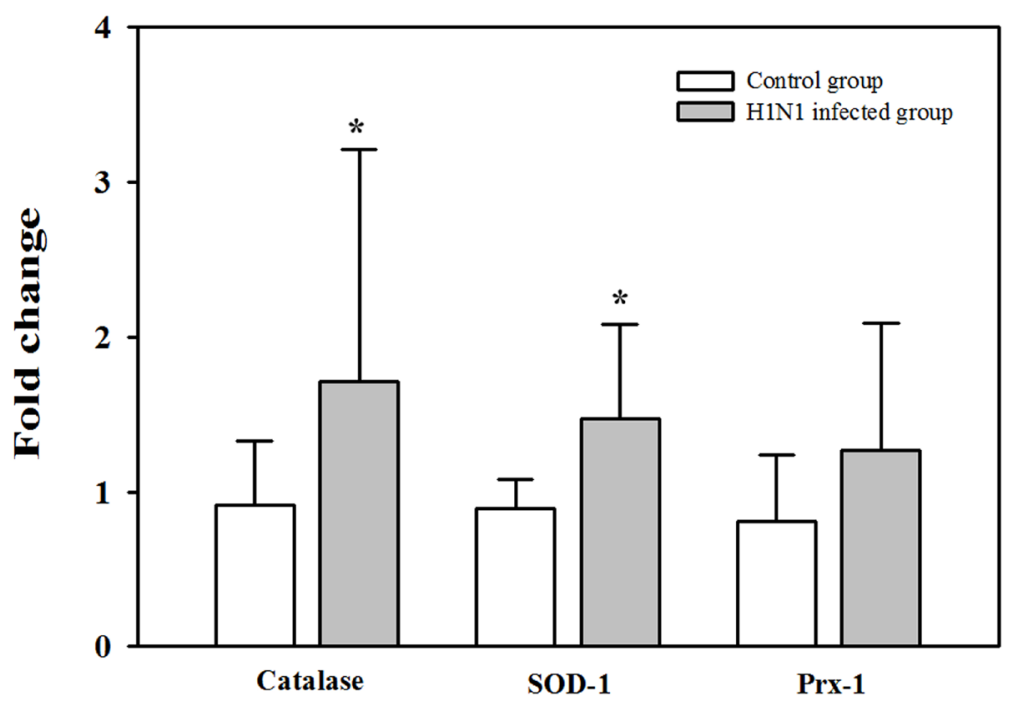

Fig. 4

Plasma and blood levels of antioxidant enzymes

(a) Western blot analysis was conducted to determine the protein expression of antioxidant enzymes in the plasma of non-infected control group ( $\mathrm{n}=15$ ) and H1N1 infected group $(n=15)$. Graphs are showing changes in the levels of SOD-1, catalase, and Prx-1. Quantities of enzymes are relative to $\alpha$-tubulin. (b) RT-PCR was conducted to determine the gene expression of antioxidant enzymes in the whole blood obtained from non-infected control group ( $\mathrm{n}=15)$ and H1N1 infected group $(\mathrm{n}=15)$. Asterisk indicates a significant difference. 

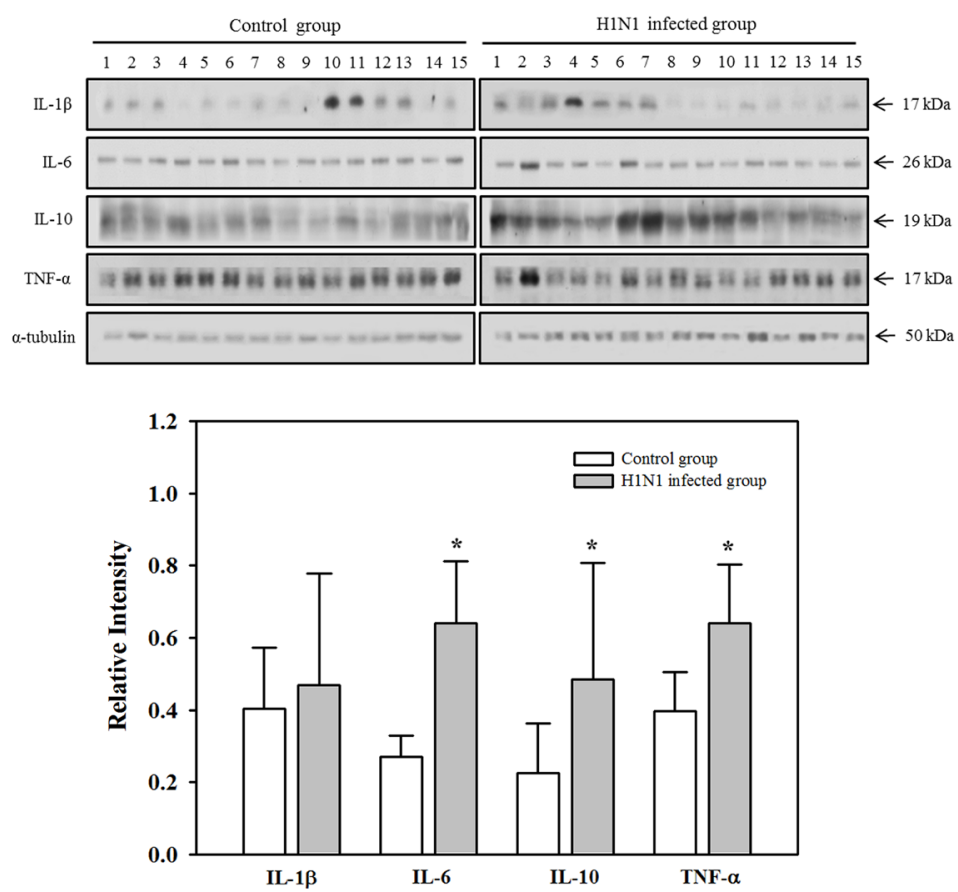

Fig. 5

Plasma cytokine levels

Western blot analysis was conducted to determine the expression of cytokines in the plasma from non-infected control group ( $\mathrm{n}=15$ ) and H1N1 infected group $(\mathrm{n}=15)$. Graphs showing changes in the levels of IL-1, IL-6, IL-10, and TNF- $\alpha$ and quantities of enzymes are relative to $\alpha$-tubulin. Asterisk indicates a significant difference.
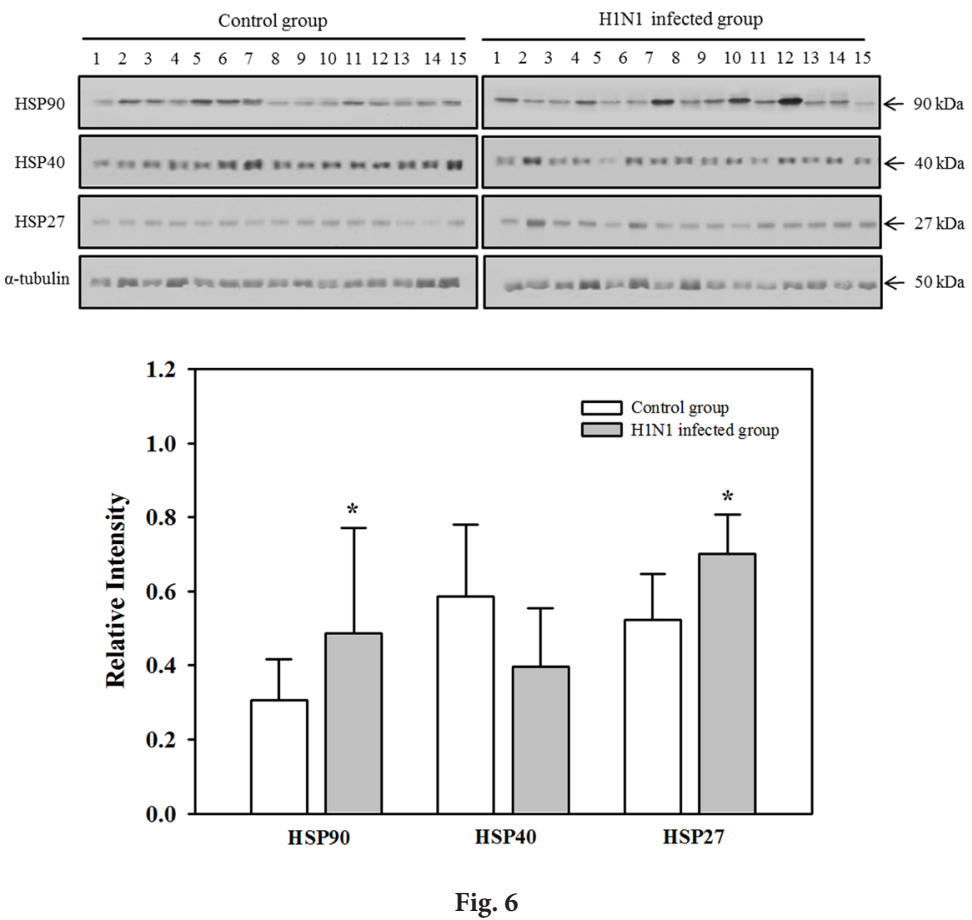

Plasma HSP levels

Western blot analysis was conducted to determine the expression of HSP in the plasma from non-infected control group ( $\mathrm{n}=15$ ) and H1N1 infected group $(n=15)$. Graphs are showing changes in the levels of HSP27, HSP40, and HSP90. Quantities of enzymes are relative to $\alpha$-tubulin. Asterisk indicates a significant difference. 
Western blot analysis of HSP27, HSP40, and HSP90 was conducted using the plasma obtained from the H1N1 infected group and control group (Fig. 6). The relative intensities of HSP40 did not differ significantly between the two groups. However, the intensities of HSP27 and HSP90 were significantly greater in the H1N1 infected group than in the control group.

\section{Discussion}

In the present study, the levels of MDA and carbonyl contents in the plasma and 8-OhdG concentration in the urine were determined to evaluate the oxidative damage to DNA, lipids, and proteins in $\mathrm{H} 1 \mathrm{~N} 1$ infected patients and the non-infected control subjects. 8-OhdG is one of the predominant forms of free radical-induced lesions of DNA and is excreted into the urine. The urinary 8-OhdG is considered as an important biomarker of generalized and cellular oxidative stress to DNA (Nakajima et al., 2012). In this study, the level of urinary 8-OhdG was significantly higher in $\mathrm{H} 1 \mathrm{~N} 1$ infected patients than in the control subjects. It has been reported that DNA damage is induced in human leucocytes infected by the influenza virus, and the DNA damage due to influenza virus infection is believed to be related to apoptosis (Vijaya et al., 1999; Wiwanitkit, 2010). Lipid peroxidation and protein oxidation were also increased in the plasma of H1N1 infected patients. Recently, lipid peroxidation and protein oxidation have become the subject of interest and they have been performed as biomarkers of oxidative damage in human studies (Orhan et al., 2004). Specifically, the finding of an enhanced lipid peroxidation level in the plasma of H1N1 infected patients is similar to that in the other studies, providing evidence for the presence of oxidative stress during influenza virus infection (Stoeva et al., 2001; Mileva et al., 2002; Kumar et al., 2003).

Antioxidant enzymes, including SOD, catalase, GPx, HO, Prx, and IDO, play a role in protective effects on oxidative stress against influenza virus infection (Jacoby and Choi, 1994; Choi et al., 1996; Shi et al., 2010; Yamada et al., 2012; Yatmaz et al., 2013). The expressions of three antioxidant enzymes, such as SOD-1, Prx-1, and catalase, were assessed at both protein and mRNA levels in the plasma and lymphocytes of H1N1 infected patients and the control subjects. A significant increase was found in the expression of SOD-1 and catalase, but not in the expression of Prx-1 in the H1N1 infected patients. The results provide evidence that SOD-1 and catalase play major roles in protection against an increase in generation of free radicals during influenza virus infection.

In general, the innate immune system is the first line of defense against viruses by induction of the expression of cytokines and chemokines (Yu et al., 2011). Cytokine activation usually occurs much earlier than the clinically observable response, and it may play an important role in stimulating an immune response to the H1N1 virus infection (Wen et al., 2011). A whole range of cytokines, including IL-1, IL-2, IL-6, IL-8, IL-10, IL-15, IL-18, and TNF- $\alpha$ are induced during an influenza virus infection in different cell types (Mogensen and Paludan, 2001). In the present study, the levels of cytokines, such as IL-1, IL-6, IL-10, and TNF- $\alpha$ were assessed in the plasma of H1N1 infected patients and the control subjects. A significant elevation of IL-6, IL-10, and TNF- $\alpha$ levels was observed in H1N1 infected patients. The enhanced cytokine expression during $\mathrm{H} 1 \mathrm{~N} 1$ virus infection is in concordance with other human studies (Arankalle et al., 2010; Hasegawa et al., 2011; Yu et al., 2011). It has also been reported that IL-6 might act as the mediator in induction of IL-10 production, which leads to disease progression (Yu et al., 2011).

HSPs are important chaperone proteins that are produced endogenously. HSPs are named according to their molecular weight, such as HSP90, HSP70, HSP60, and small heat-shock proteins. HSPs are induced in response to a variety of stressors, including elevated temperature, hypoxia, inflammation, and ischemia (Benjamin and McMillan, 1998). In this study, the expression of HSP27, HSP40, and HSP90 were assessed in the plasma of H1N1 infected patients and the control subjects, and significant increases in HSP27 and HSP90 expression were found in H1N1 infected patients than in the control subjects. HSP27 has a strong protective activity against a number of cytotoxic agents, including heat shock, oxidative stress, chemotherapeutic agents, and cytokines (Charette et al., 2000). It may also play the role as a potential biomarker of disease and therapeutic target (Vidyasagar et al., 2012). In a proteomic study, HSP27 was found to be upregulated in A549 human lung carcinoma cells infected with an influenza virus (Vester et al., 2009). In addition, Li et al. (2012) reported that HSP27 enhanced the inhibitory effect of influenza virus NS1 on the expression of interferon beta.

In summary, we investigated the expression of HSPs, cytokines, anti-oxidant enzymes, and oxidative damage to the DNA, lipids, and proteins in patients infected with 2011 H1N1 influenza virus. The levels of SOD, catalase, IL-6, $1 \mathrm{~L}-10$, TNF- $\alpha, \mathrm{HSP} 90$, and HSP27 were significantly greater in the H1N1 infected group than in the non-infected control group. In addition, the levels of DNA damage, lipid peroxidation and protein oxidation were significantly higher in the H1N1 infected group than in the non-infected control group. Our results suggest that SOD, catalase, IL-6, IL-10, TNF- $\alpha$, HSP90, and HSP27 play an important role in H1N1 virus infection, and $\mathrm{H} 1 \mathrm{~N} 1$ influenza virus was found to be a strong inducer of oxidative damage in DNA, lipids, and proteins.

Acknowledgements. This work was supported by the grant (No. A103001) from TEPIK (Transgovernmental Enterprise for Pandemic Influenza in Korea), which is part of Korea Healthcare technology R\&D Project by Ministry of Health \& Welfare, Republic of Korea. 


\section{References}

Arankalle VA, Lole KS, Arya RP, Tripathy AS, Ramdasi AY, Chadha MS, Sangle SA, Kadam DB (2010): Role of host immune response and viral load in the differential outcome of pandemic H1N1 (2009) influenza virus infection in Indian patients. PLoS One 5, e13099. http://dx.doi.org/10.1371/ journal.pone.0013099

Benjamin IJ, McMillan DR (1998): Stress (heat shock) proteins: molecular chaperones in cardiovascular biology and disease. Circ. Res. 83, 117-132. http://dx.doi.org/10.1161/01. RES.83.2.117

Charette SJ, Lavoie JN, Lambert H, Landry J (2000): Inhibition of Daxx-mediated apoptosis by heat shock protein 27 . Mol. Cell. Biol. 20, 7602-7612. http://dx.doi.org/10.1128/ MCB.20.20.7602-7612.2000

Choi K, Cho SI, Hashizume M, Kim H (2012): Epidemiological characteristics of novel influenza A (H1N1) in antiviral drug users in Korea. PLoS One 7, e47634. http://dx.doi. org/10.1371/journal.pone.0047634

Choi AM, Knobil K, Otterbein SL, Eastman DA, Jacoby DB (1996): Oxidant stress responses in influenza virus pneumonia: gene expression and transcription factor activation. Am. J. Physiol. 271, L383-L391.

Damjanovic D, Divangahi M, Kugathasan K, Small CL, Zganiacz A, Brown EG, Hogaboam CM, Gauldie J, Xing Z (2011): Negative regulation of lung inflammation and immunopathology by TNF- $\alpha$ during acute influenza infection. Am. J. Pathol. 179, 2963-2976. http://dx.doi. org/10.1016/j.ajpath.2011.09.003

Gao W, Mao Q, Feng AW, Sun HM, Sun WK, Lu X, Su X, Shi Y (2011): Inhibition of pre-B cell colony-enhancing factor attenuates inflammation and apoptosis induced by pandemic H1N1 2009 in lung endothelium. Respir. Physiol. Neurobiol. 178, 235-241. http://dx.doi.org/10.1016/j. resp.2011.06.016

Hasegawa S, Matsushige T, Inoue H, Shirabe K, Fukano R, Ichiyama $\mathrm{T}$ (2011): Serum and cerebrospinal fluid cytokine profile of patients with 2009 pandemic H1N1 influenza virusassociated encephalopathy. Cytokine 54, 167-172. http:// dx.doi.org/10.1016/j.cyto.2011.01.006

Jacoby DB, Choi AM (1994): Influenza virus induces expression of antioxidant genes in human epithelial cells. Free Radic. Biol. Med. 16, 821-824. http://dx.doi.org/10.1016/08915849(94)90198-8

Kim H, Oh E, Im H, Mun J, Yang M, Khim JY, Lee E, Lim SH, Kong MH, Lee M, Sul D (2006): Oxidative damages in the DNA, lipids, and proteins of rats exposed to isofluranes and alcohols. Toxicology 220, 169-178. http://dx.doi. org/10.1016/j.tox.2005.12.010

Kohen R, Nyska A (2002): Oxidation of biological systems: oxidative stress phenomena, antioxidants, redox reactions, and methods for their quantification. Toxicol. Pathol. 30, 620650. http://dx.doi.org/10.1080/01926230290166724

Kumar P, Sharma S, Khanna M, Raj HG (2003): Effect of Quercetin on lipid peroxidation and changes in lung morphology in experimental influenza virus infection. Int. J. Exp.
Pathol. 84, 127-133. http://dx.doi.org/10.1046/j.13652613.2003.00344.x

Li Z, Liu X, Zhao Z, Liu W (2012): Heat shock protein 27 enhances the inhibitory effect of influenza A virus NS1 on the expression of interferon-beta. Sheng Wu Gong Cheng Xue Bao 28, 1205-1215.

Mileva M, Bakalova R, Tancheva L, Galabov S (2002): Effect of immobilization, cold and cold-restraint stress on liver monooxygenase activity and lipid peroxidation of influenza virus-infected mice. Arch. Toxicol. 76, 96-103. http://dx.doi.org/10.1007/s00204-001-0306-6

Mogensen TH, Paludan SR (2001): Molecular pathways in virusinduced cytokine production. Microbiol. Mol. Biol. Rev. 65, 131-150. http://dx.doi.org/10.1128/MMBR.65.1.131$\underline{150.2001}$

Nakajima H, Unoda K, Ito T, Kitaoka H, Kimura F, Hanafusa T (2012): The relation of urinary 8-OHdG, a marker of oxidative stress to DNA, and clinical outcomes for ischemic stroke. Open Neurol. J. 6, 51-57. http://dx.doi. org/10.2174/1874205X01206010051

Nikam SV, Nikam PS, Chandrashekar MR, Kalsad ST, Jnaneshwara KB (2010): Role of lipid peroxidation, glutathione and antioxidant enzymes in H1N1 Influenza. Biomed. Res. 21, 457-560.

Orhan H, Holland BV, Krab B, Moeken J, Vermeulen NPE, Hollander P, Meerman JH (2004): Evaluation of a multiparameter biomarker set for oxidative damage in man: increase urinary excretion of lipid, protein and DNA oxidation products after one hour of exercise. Free Radic. Res. 38, 1269-1279. http://dx.doi.org/10.1080/10715760400013763

Sharma K, Tripathi S, Ranjan P, Kumar P, Garten R, Deyde V, Katz JM, Cox NJ, Lal RB, Sambhara S, Lal SK (2011): Influenza A virus nucleoprotein exploits Hsp40 to inhibit PKR activation. PLoS One 6, e20215. http://dx.doi.org/10.1371/ journal.pone.0020215

Shi XL, Shi ZH, Huang H, Zhu HG, Zhou P, Ju D (2010): Therapeutic effect of recombinant human catalase on $\mathrm{H} 1 \mathrm{~N} 1$ influenzainduced pneumonia in mice. Inflammation 33, 166-172. http://dx.doi.org/10.1007/s10753-009-9170-y

Stoeva E, Tantcheva L, Mileva M, Savov V, Galabov AS, Braykova A (2001): Preventive effect of vitamin E on the processes of free radical lipid peroxidation and monooxygenase enzyme activity in experimental influenza virus infection. Adv. Exp. Med. Biol. 500, 257-260. http://dx.doi. org/10.1007/978-1-4615-0667-6 40

Vester D, Rapp E, Gade D, Genzel Y, Reichl U (2009): Quantitative analysis of cellular proteome alterations in human influenza A virus-infected mammalian cell lines. Proteomics 9, 3316-3327. http://dx.doi.org/10.1002/pmic.200800893

Vidyasagar A, Wilson NA, Djamali A (2012): Heat shock protein 27 (HSP27): biomarker of disease and therapeutic target. Fibrogenesis Tissue Repair 5, 7. http://dx.doi. org/10.1186/1755-1536-5-7

Vijaya Lakshmi AN, Ramana MV, Vijayashree B, Ahuja YR, Sharma G (1999): Detection of influenza virus induced DNA damage by comet assay. Mutat. Res. 442, 53-58. http:// dx.doi.org/10.1016/S1383-5718(99)00058-3 
Watanabe K, Fuse T, Asano I, Tsukahara F, Maru Y, Nagata K, Kitazato K, Kobayashi N (2006): Identification of Hsc70 as an influenza virus matrix protein (M1) binding factor involved in the virus life cycle. FEBS Lett. 580, 5785-5790. http://dx.doi.org/10.1016/j.febslet.2006.09.040

Wen Y, Deng BC, Zhou Y, Wang Y, Cui W, Wang W, Liu P (2011): Immunological features in patients with pneumonitis due to influenza A H1N1 infection. J. Investig. Allergol. Clin. Immunol. 21, 44-50.

Wiwanitkit V (2010): DNA damage and mutagenesis: is it an issue for swine flu? Malays J. Pathol. 32, 143.

Yamada Y, Limmon GV, Zheng D, Li N, Li L, Yin L, Chow VT, Chen J, Engelward BP (2012): Major shifts in the spatiotemporal distribution of lung antioxidant enzymes during influenza pneumonia. PLoS One 7, e31494. http://dx.doi. org/10.1371/journal.pone.0031494

Yatmaz S, Seow HJ, Gualano RC, Wong ZX, Stambas J, Selemidis S, Crack PJ, Bozinovski S, Anderson GP, Vlahos R (2013): Glu- tathione peroxidase-1 (GPx-1) reduces influenza A virusinduced lung inflammation. Am. J. Respir. Cell. Mol. Biol. 48, 17-26. http://dx.doi.org/10.1165/rcmb.2011-0345OC

Yu X, Zhang X, Zhao B, Wang J, Zhu Z, Teng Z, Shao J, Shen J, Gao Y, Yuan Z, Wu F (2011) Intensive cytokine induction in pandemic H1N1 influenza virus infection accompanied by robust production of IL-10 and IL-6. PLoS One 6, e28680. http://dx.doi.org/10.1371/journal.pone.0028680

Zhang C, Yang Y, Zhou X, Yang Z, Liu X, Cao Z, Song H, He Y, Huang P (2011): The NS1 protein of influenza A virus interacts with heat shock protein Hsp90 in human alveolar basal epithelial cells: implication for virus-induced apoptosis. Virol. J. 8, 181. http://dx.doi.org/10.1186/1743422X-8-181 